\title{
慢性透析患者における内シャントの穿刺ミスの検討
}

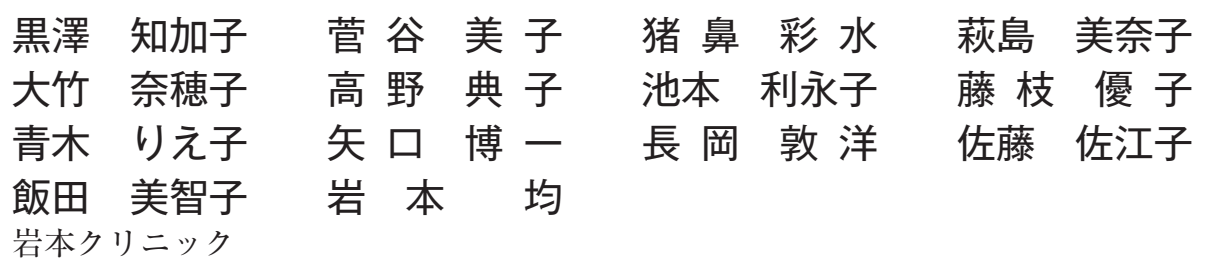

キーワード：バスキュラーアクセス, 内シャント, 穿刺ミス, 穿刺ミスの分類

〈要旨〉

穿刺技術を向上させミスなく穿刺をすることは，バスキュラーアクセスの良好な管理に重要である. 当院では 3 年前より, 穿刺ミスを少なくする取り組みを行ってきた. 今回, 1 年間の内シャントの穿刺ミスについて頻度, 原 因, 発生状況を調べた. 調査期間は 2010 年 1 月 12 月で, 当院でのすべての内シャント穿刺を対象とした. 穿刺 ミスの調査にはミスを記入するノートを活用した. 穿刺ミスは $A, V$ 側のいずれか一方でも 1 回目の穿刺に失敗し た場合を穿刺ミスと判定し, 発生時期により, (1) 連続ミス, (2) 1 週間以内のミス, (3) 散発ミスの三つに分類した. 1 年間の内シャントを使用した透析回数は 15,101 回であり, その内, 穿刺ミスをした透析回数は 215 回で $1.4 \%$ で あった. 穿刺ミスが少なかった要因として, 以前より行ってきた穿刺ミスに対する取り組みの効果が考えられる. 分類別では, 連続ミスは 15 回 (7\%), 1 週間以内のミスは 19 回 $(9 \%)$, 散発ミスは 181 回 (84\%) で, 散発ミスが 大部分であった. 連続ミス, 1 週間以内のミスは少なかったが, これは次の透析日の朝の申し送りでミスの内容を スタッフに報告していることと, 穿刺ミスノートに全てのミスの内容を具体的に記入したことが影響していると思 われる. また, 穿刺ミスの大部分を占める散発ミスの発生には, 穿刺者の集中力の低下が大きく関係していると思 われた. 穿刺者が集中力を失わないことで, さらに散発ミスを減らせる可能性があると思われる.

\section{A study of mispuncture for arteriovenous shunts in chronic hemodialysis patients}

Chikako Kurosawa, Yoshiko Sugaya, Ayami Inohana, Minako Hagishima, Naoko Otake, Noriko Takano, Rieko Ikemoto, Yuko Fujieda, Rieko Aoki, Hirokazu Yaguchi, Atsuhiro Nagaoka, Saeko Sato, Michiko lida and Hitoshi Iwamoto

Iwamoto Clinic

Key words : vascular access, arteriovenous shunt, mispuncture, classification of mispuncture

$\langle$ Abstract〉

For maintaining favorable vascular access, it is important to improve the puncture technique and puncture without error. In our clinic, we have made an effort to reduce vascular access mispuncture from three years ago. This time, we examined the frequency, cause and situation regarding the mispuncture of arteriovenous shunts over a 1-year period. All punctures for arteriovenous shunts in chronic hemodialysis patients were studied from January to December 2010. The miss notebook in which mispunctures had been recorded was utilized for an investigation of mispuncture. It was judged to be a mispuncture when one of the arterial or venous side veins failed in the first puncture. The mispuncture was classified by time of occurrence into the following three groups : (1) consecutive miss, (2) miss within one week, (3) sporadic miss. The total number of dialysis procedures employing arteriovenous shunts was 15,101 and the number of dialysis procedures involving a mispuncture was $215(1.4 \%)$. This low rate is regarded as the effect of the previous effort to avoid mispuncture. Based on the

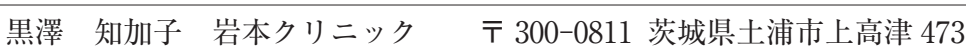

Chikako Kurosawa Tel : 029-826-6360 Fax : 029-826-6362

〔受付日：2011 年 5 月 11 日, 受理日：2011 年 7 月 27 日] 
classification, consecutive misses numbered 15(7\%), misses within one week numbered 19(9\%), and sporadic misses, the majority, numbered $181(84 \%)$. There were few consecutive misses and misses within one week. This may be due to the effect of reporting the contents of the miss notebook to the medical staff in the morning conference on the next dialysis day. In addition, sporadic misses, comprising the majority of mispunctures, were related to the poor concentration of medical staff. We think that it is possible to reduce sporadic misses by maintaining concentration during puncture.

\section{I 、緒言と目的}

透析医療は進歩を続けている。慢性透析患者の延命 はもとより，さらなる QOL（quality of life）の向上を 目指してスタッフも日々努力, 研究している. しかし, 血液透析は 1 日おきに行わなければならず，透析療法 自体が患者にとって身体的，精神的負担となる．特に バスキュラーアクセスの穿刺行為は，透析患者にとっ てとても不安なものであり，かつ重要なものである. 穿刺技術を向上させトラブルなく穿刺をすることは, バスキュラーアクセスを長持ちさせる良好な管理につ ながり，また患者の苦痛を軽減するとともに安心感を 与え，スタッフへの信頼につながる．当院では 2007 年より，透析導入して日が浅い患者や穿刺が難しい患 者の血管穿刺は経験年数の長い特定のスタッフで行っ たり，新しい患者や穿刺ミスの続いた患者については 検討会を行うなど，穿刺ミスを少なくする取り組みを 行ってきた. 今回は, 慢性透析患者のバスキュラーア クセスの中で大部分を占める内シャントの穿刺につい て, 当院での 1 年間の穿刺ミスの頻度, 原因, 発生状 況を調べた.

\section{II. 対象と方法}

\section{1. 対 象}

2010 年 1 月〜 12 月の 1 年間における当院でのすべ ての内シャント穿刺を対象とした。内シャント穿刺の
対象患者は 108 名で，年齢は 36 歳～ 89 歳（平均年歯 $66.7 \pm 11.3$ 歳), 透析歴は 14 日 30 年 (平均透析歴 $6.9 \pm 6.5$ 年）であった. 対象患者は全員週 3 回の慢性 透析患者で，透析延べ回数は 15,101 回だった。なお， 年齢，透析歴は 2010 年 1 月 1 日時点のもので, 2010 年に当院へ転入してきた患者は, 転入時点のものとし た.

\section{2. 穿刺ミスの調査方法}

穿刺ミスを記入するノート（穿刺ミスノート）を作 り，実際に穿刺ミスをしたスタッフがミスの内容を記 入した。また，毎日その日の責任者が穿刺ミスの記入 漏れがないかチェックし, 記入漏れがある場合は即日, 穿刺スタッフに記入させ，翌日に持ち越さないよう管 理した。

\section{3. 穿刺ミスの頻度と分類（図 1)}

穿刺ミスは， $\mathrm{A}$ 側， V 側のいずれか一方でも 1 回目 の穿刺に失敗した場合を穿刺ミスと判定した。また， 同一透析で $\mathrm{A}$ 側， $\mathrm{V}$ 側の両側とも穿刺ミスをした場 合でも穿刺ミス 1 回とカウントした. なお，当院では 内シャントの穿刺，血液透析の開始操作は，基本的に 1 名のスタッフで行っているが， A 側と V 側の穿刺が 完全に終了してから回路への接続, 機械の操作を行っ ている. 穿刺ミスの分類は発生時期により以下の三つ に分けた。これは，穿刺ミスにより生じる局所の腫脹 や血管の変化が，その後の穿刺を難しくする可能性を 考慮したためである

(1) 連続ミス…前回の穿刺ミスに連続して次の透析 時に起こった穿刺ミス

\begin{tabular}{|c|c|c|c|c|c|c|c|c|c|c|c|c|c|c|c|c|}
\hline 透析日 & $\begin{array}{l}\text { 月 } \\
\text { 火 }\end{array}$ & $\begin{array}{l}\text { 水 } \\
\text { 木 }\end{array}$ & $\begin{array}{l}\text { 金 } \\
\text { 土 }\end{array}$ & $\begin{array}{l}\text { 月 } \\
\text { 火 }\end{array}$ & $\begin{array}{l}\text { 水 } \\
\text { 木 }\end{array}$ & $\begin{array}{l}\text { 金 } \\
\text { 土 }\end{array}$ & $\begin{array}{l}\text { 月 } \\
\text { 火 }\end{array}$ & $\begin{array}{l}\text { 水 } \\
\text { 木 }\end{array}$ & $\begin{array}{l}\text { 金 } \\
\text { 土 }\end{array}$ & $\begin{array}{l}\text { 月 } \\
\text { 火 }\end{array}$ & $\begin{array}{l}\text { 水 } \\
\text { 木 }\end{array}$ & $\begin{array}{l}\text { 金 } \\
\text { 土 }\end{array}$ & $\begin{array}{l}\text { 月 } \\
\text { 火 }\end{array}$ & $\begin{array}{l}\text { 水 } \\
\text { 木 }\end{array}$ & $\begin{array}{l}\text { 金 } \\
\text { 土 }\end{array}$ & $\begin{array}{l}\text { 月 } \\
\text { 火 }\end{array}$ \\
\hline 穿刺ミス & $i s$ & & & & $\hat{s}$ & () & & $\triangle$ & (a) & & & $\triangle$ & & & & 放 \\
\hline
\end{tabular}

\begin{tabular}{c|c|c}
\hline I & 連続ミス & $\bigcirc$ \\
\hline II & $\begin{array}{c}\text { 1週間以内のミス } \\
\text { (連続ミスを除く) }\end{array}$ & $\triangle$ \\
\hline III & 散発ミス & 袹 \\
\hline
\end{tabular}

図 1 穿刺ミスの分類 
表 1 穿刺ミスノートの記入内容と集計結果

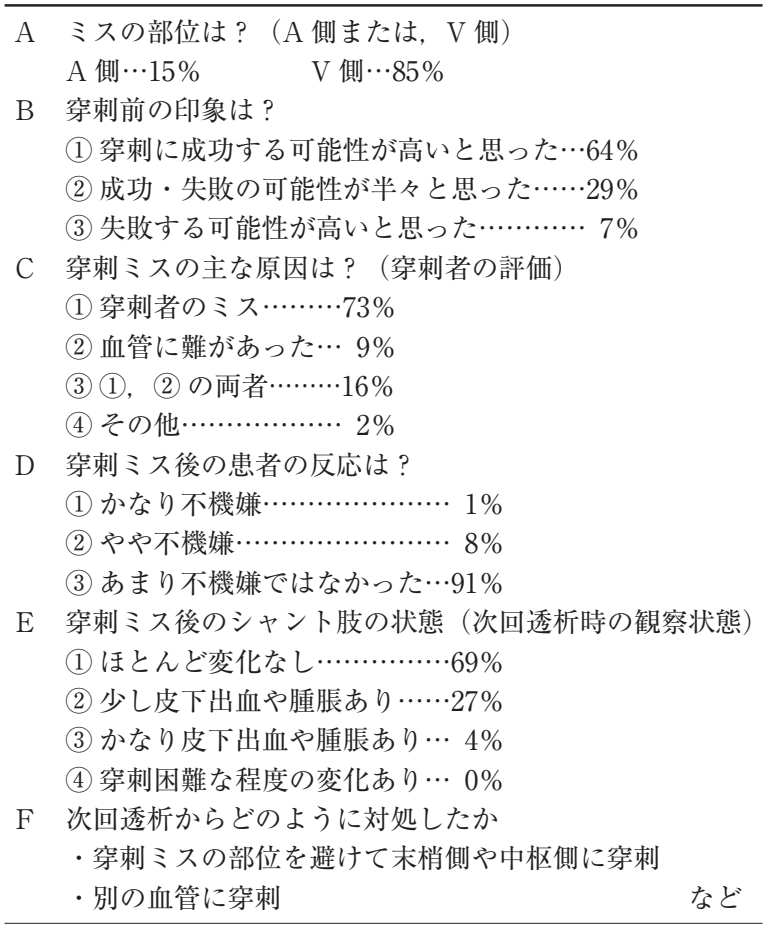

(2) 1 週間以内のミス …前回の穿刺ミス後, 1 週間以 内に起こった穿刺ミス

(3) 散発ミス…(1) (2) 以外の穿刺ミス

\section{4. 穿刺ミスノートの記入内容（表 1）}

ミスの部位は $\mathrm{A}$ 側, $\mathrm{V}$ 側のどちらか, 穿刺前の穿刺 者の印象もしくは穿刺に対する自信の程度, 穿刺者の 考えるミスの原因は何か, これはより具体的に, 穿刺 者のミスか, 血管に難があったか (細かった, もろかっ た，深かった，浅かった，曲がっていたなど)，その両 方なのかを記入できるようにした，また，穿刺ミス後 の患者の反応はどうだったのかを，穿刺ミスをしたス タッフが記入した．穿刺ミス後の次の透析時には別の 穿刺者がシャント肢の状態を記入し，どのように穿刺 したか（いつもの部位に穿刺可能か, 皮下出血や腫脹 がひどく通常穿刺している血管とは異なる血管に穿刺 しなければならないかなど）を記載した。また，備考 欄を設け，今後の注意点や対策を記入できるようにし た.

なお，記入したミス内容は次回透析日の朝の申し送 りでスタッフ全員に報告した.

穿刺担当のスタッフは, 看護師 13 名, 臨床工学技士 2 名で, 透析業務の穿刺操作に従事した経験年数は 0 日〜25 年（平均 $10.1 \pm 6.6$ 年）であった。 なお, 経験 年数は 2010 年 1 月 1 日時点とし, 2010 年に当院へ入 職したスタッフは, 入職後の穿刺操作を開始した時点 とした. スタッフの経験年数は, 1 年未満が 2 名, 1
表 2 穿刺ミスの分類別の回数と割合

\begin{tabular}{c|c|c|c}
\hline & & 回数 & 割合 \\
\hline I & 連続ミス & 15 回 & $7 \%$ \\
\hline II & $\begin{array}{c}1 \text { 週間以内のミス } \\
\text { (連続ミスを除く) }\end{array}$ & 19 回 & $9 \%$ \\
\hline III & 散発ミス & 181 回 & $84 \%$ \\
\hline
\end{tabular}

年〜 5 年未満が 1 名, 5 年 10 年未満が 3 名, 10 年以 上が 9 名だった。

\section{III. 結果}

1 年間の内シャントを使用した透析回数は 15,101 回であり，そのうち穿刺ミスをした透析回数は 215 回 で $1.4 \%$ でった．対象患者 108 名のうち， 45 名で穿 刺ミスは 1 回もなく, 63 名で穿刺ミスが 1 回以上発生 した．穿刺ミスの回数は, 1 回が 23 名 $(36.5 \%), 2$ 5 回が 31 名 $(49.2 \%), 6 \sim 10$ 回が 5 名 (7.9\%), 11 回 以上が 4 名 $(6.4 \%)$ であった. 11 回以上穿刺ミスの あった 4 名は, 穿刺可能範囲が狭く血管も細く, 穿刺 が難しい血管であった。 なお，同一透析で $\mathrm{A}$ 側， $\mathrm{V}$ 側 の両側とも穿刺ミスをした例はなかった. 分類別の穿 刺ミスの回数と割合を表 2 に示す。連続ミスが 15 回 (7\%), 1 週間以内のミスが 19 回 $(9 \%)$, 散発ミスが 181 回 (84\%) で, 散発ミスが大部分であった.

穿刺ミスノートの集計結果を表 1 に示す. 穿刺ミス の部位は， $\mathrm{A}$ 側が $15 \%, \mathrm{~V}$ 側が $85 \%$ であった。穿刺 前の穿刺者の印象は, 「穿刺に成功する確率は高いと 思った」が $64 \%$,「成功, 失敗の可能性は半々と思っ た」が $29 \%$,「失敗する可能性は高いと思った」が $7 \%$ で， 6 割以上が自信を持って穿刺に臨んでいた．穿刺 者の考える穿刺ミスの主な原因は，「穿刺者のミス」が $73 \%$ と多く，「血管に難があった」が $9 \%$,「その両者」

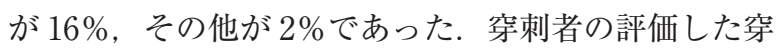
刺ミス後の患者の反応は,「あまり不機嫌ではなかっ た」が $91 \%$ と大部分だった. 穿刺ミス後のシャント肢 の状態については, 次回透析時のスタッフの観察で, 「ほとんど変化なし」が $69 \%$,「少し皮下出血や腫脹あ

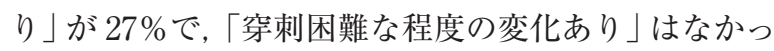
た。

\section{IV. 考察}

内シャントの穿刺方法や管理についての総説はいく つかあるが ${ }^{1 \sim 4)}$, 穿刺ミスの実際の頻度についての報 告は, 著者らが調べた限り見当たらない. その点で今 
回の報告は意義があるものと思われる.

穿刺ミス頻度は $1.4 \%$ と予想していたよりもかなり 少なかった．これは 2007 年から行ってきた穿刺ミス に対する取り組みの効果と考えられる。ささらに，ス タッフの透析従事年数が平均 10.1 年と比較的長いス タッフが多かったことも関係していると思われる。な お，穿刺ミスノートへの記録は，穿刺担当者と当日の 責任者でダブルチェックをしており，記録漏れはない ものと考えている.

穿刺ミスを発生時期より三つに分類して検討した が，これにより散発ミスが $84 \%$ と多く，穿刺がより難 しいと思われる穿刺ミス後の連続ミスや 1 週間以内の ミスが少ないことが判明した。連続ミスと 1 週間以内 のミスは，以前の穿刺ミスによる血管の変化や局所の 腫脹が原因となって起こりやすいが，散発ミスに比べ てはるかに少なかった。 これは，次の透析日の朝の申 し送りでミスの内容をスタッフに報告したことで，全 てのスタッフが穿刺ミスのあった患者を把握すること ができ，さらに穿刺するスタッフがより慎重に穿刺し たためと思われる。一方，散発ミスは前回の穿刺ミス から少なくとも 1 週間以上経過しているため, 局所の 腫脹などがあまりなく, 穿刺がより容易と思われるが, 実際には多く発生していた。この散発ミスが多い原因 としては, 穿刺前の穿刺者の印象で，64\%が穿刺に自 信を持っていたこと，また穿刺ミス後の穿刺者の評価 で $73 \%$ が穿刺者のミスと認めていること，などを考え 合わせると，穿刺者の集中力の低下が主なものと推測 される，穿刺しやすい血管でも，また得意な血管でも， 穿刺者の集中力の低下が原因で穿刺を失敗してしまう ことが多いといえる．集中力低下の要因としては，毎 日何人もの穿刺を行っているため慣れが生じ, 穿刺行 為自体が流れ作業的になって注意散漫となることが, まずあげられる。ささらに，穿刺時に患者から話しかけ られると，それに対応することなども集中力低下の要 因となる。しかしながら，穿刺ミスが起こりやすい患 者は穿刺可能範囲が狭く血管も細く，穿刺が難しい血 管であることも事実で，そのような患者に穿刺ミスが 多い傾向も明らかになった.

また，穿刺ミスは $\mathrm{A}$ 側より V 側で多かったが，こ れは $\mathrm{A}$ 側で使用する血管は $\mathrm{V}$ 側より動静脈吻合部に 近いため, 比較的太くなっていて穿刺が易しいためと 思われる。

すべての穿刺ミスについて，ミスの部位や状況，穿 刺者の考えるミスの原因など，誰が見ても分かりやす い形式で穿刺ミスノートに記録し集計したが，これに より実際にミスをしたスタッフだけでなく，それ以外
のその場にいなかった，ミスの状況を知らないスタッ フも，それぞれの穿刺ミスを客観的にとらえることが できるようになった，加えて，記録に際してすべて記 名としたので，スタッフ個々の穿刺技術の程度が明確 になった。 それにより, 経験年数の短いスタッフは自 分の苦手な血管を把握できるようになり，経験年数の 長いスタッフは, 短いスタッフの個々の穿刺ミスの傾 向を把握でき，より指導しやすくなったと思われる.

血液透析療法は，血管を穿刺することから始まり， 穿刺ができなければ透析を行うことができない.その ような状況下では, 特に新人スタッフは重圧から過度 に緊張しやすく，また経験年数の長いスタッフでも， 以前に穿刺を失敗した患者の穿刺には重圧を感じる。 さらに，連続して失敗すれば苦手意識を持つことにつ ながる。一度持ってしまった苦手意識を払拭するに は，ミスの原因を検討評価し，また自分のミスの傾向 を把握し修正していく必要があるが, その対策として 今回使用した穿刺ミスノートは役に立つものであると いえる.

バスキュラーアクセスを長持ちさせ，良好に管理し ていくためには，穿刺ミスによる血管の硬化や局所の 腫脹を起こさないことが重要である，そのためには， なるべく連続ミスをしないことが大切となってくる. 今回の集計で連続ミスは少なかったが, 穿刺ミスノー トの記入とその申し送りが，連続ミスを減らす上で有 効であったと思われる. 穿刺ミスの大部分が散発ミス であること, そしてその発生には穿刺者の集中力の低 下が関係していることが推測されることから，さらに 散発ミスを減らせる可能性があると思われる。今後は さらなる穿刺技術の向上を目指し，穿刺ミスノートの より有効な活用法を考え, 穿刺ミスをできるだけゼロ に近づけ少しでも患者の穿刺への不安を取り除けるよ うに努力していきたい.

\section{結＼cjkstart語}

1 年間のすべての内シャント穿刺について, 穿刺ミ スノートを作り穿刺ミスの回数, 頻度, 発生状況など を調べた。

1. 穿刺ミスの頻度は $1.4 \%$ であった。

2. 穿刺ミスを発生時期より連続ミス, 1 週間以内の ミス, 散発ミスの三つに分類すると, 散発ミスが $84 \%$ と多かった。

3. 散発ミスの原因として, 穿刺者の集中力の低下が 主なものと思われた。

4. 穿刺ミスノートの記入は, ミスの減少, 穿刺技術 
の評価, 指導に有用であった.

\section{文献}

1）太田和夫：内シャント使用の実際. シャント, 使用法 と合併症の対策. p28-43, 東京医学社, 東京, 1993

2) 水附裕子：透析に必要な知識・技術を習得するには一 透析室に配属された若手ナースのあなたに一。透析ケ
ア $3: 1166-1172,1997$

3）花里ゆかり，田海美子，村山清己：透析テクニック向 上講座 穿刺の上達のために。透析ケア 6:11541159,2000

4）萩原千鶴子, 東海林隆男：穿刺. シャント管理と穿刺 技術 (斎藤 明監修, 前波輝彦, 角田隆俊編), p108113, メディカ出版，大阪， 2005 